\title{
Water Quality Assessment of Jarum Mas River at Matang Mangrove Forest, Perak
}

\section{Albert Empawi Tindit ${ }^{1}$, Seca Gandaseca ${ }^{1}$, Ahmad Mustapha Mohamad Pazi ${ }^{1}$, Laurna Nyangon ${ }^{1}$}

${ }^{1}$ Department of Forest Production, Faculty of Forestry, Universiti Putra Malaysia, 43400 Serdang, Selangor Darul Ehsan Malaysia

\begin{abstract}
Mangrove Forest is well known with the mangrove tree that can withstand waves from the sea and even Tsunami. That has happened in Sri Lanka in 2004 where many villages at the mangrove area safe and the number of death reduced. However, this mangrove forest nowadays threatened by the human activities. Therefore, the study was carried out to determine the water quality index (WQI) of Jarum Mas river which near to the agriculture area and to compare the water quality during low and high tide. There were 30 samples of water taken during Jun and July at 5 stations along Jarum Mas river. The data collections were collected based on the six WQI parameters; Ammoniacal nitrogen $\left(\mathrm{NH}_{3}{ }^{-} \mathrm{N}\right)$, Biochemical Oxygen Demand (BOD), Chemical Oxygen Demand (COD), Dissolved Oxygen (DO), pH, Total Suspended Solids (TSS) with other five parameters; Electrical Conductivity (EC), Turbidity, Total Dissolved Solids (TDS), Salinity and Temperature. The results for each parameter are summarized as follow; $\mathrm{NH}_{3}-\mathrm{N}$ range (4.3-4.85 mg/l), BOD range (1.5-4.2 mg/l), COD range (1095-1405 mg/l), DO range (2.27-4.91 mg/l), pH range (6.86-6.98), TSS range (48.33-70.5mg/l), EC range (33.04-38.7 mS/cm), turbidity range (19.38-26 NTU), TDS range (20.07-22.69 mg/l), salinity range (19.5-22.03 PSU), temperature range (28.25$29.35{ }^{\circ} \mathrm{C}$ ). The WQI of Jarum Mas River is Class III which need extensive treatment for water supply and only common economic value for fishery based on Water Quality Index (WQI) and Interim National Water Quality Standards for Malaysia (INWQS) by Department of Environmental Malaysia.
\end{abstract}

Keywords: Water Quality; Mangrove Forest; Physico-chemical Parameters; Low and High Tide

It was reported that mangrove is among the most productive coastal intertidal ecosystem in the world, confined to the tropics and subtropics, which dominate approximately $75 \%$ of the world's coastline between $25^{\circ}$ $\mathrm{N}$ and $25^{\circ} \mathrm{S}$. Indonesia, Thailand, Malaysia, and India are such country in Asia where the mangrove population distributed (Alongi, 2008). Mangrove forest is the most productive ecosystem for services to the environment and people as the demand is increasing nowadays (WWF, 2013). This is why mangrove forest become the most threatened tropical ecosystem. It was reported by WWF (2013) that more than $35 \%$ of the mangroves in the world was already gone by human activities and needs. Matang Mangrove Forest is one of the mangrove forests in Malaysia that well known and well management in the world. Sustainable Forest Management has been implemented in Matang

Mangrove Forest where they did replanting to maintain the $\operatorname{logs}$ production and to achieve a sustainability management. According to Alongi (2002), mangrove forests can often be rehabilitated but not restored. Latiff (2012) was said that Matang Mangrove Forest area is 41, 617 ha which Kuala Jarum Mas is one of the mangrove forests in there. However, some of the areas in Matang Mangrove Forest nowadays has been converted into agriculture, resettlement and others. One of the main activity in there is agriculture plantation which is close to Jarum Mas river. This study is done to determine whether the agriculture plantation gives effect to the water quality status in Jarum Mas river based on the water quality parameters.

\section{MATERIAL AND METHODS}

The samples ware taken along Jarum Mas river at Matang Mangrove Forest which started from downstream, middle stream to the upstream. There were five stations were chosen along Jarum Mas river started from downstream, middle stream to the upstream with an average of distance $1 \mathrm{~km}$ between each station. The data in each station were measured by using in-situ equipment and the Global Positioning System (GPS) point of each station was recorded to locate the exact location of the sampling and to make sure that the exact location of sampling for next sampling. The water samples were also taken in 3 replications in each station for laboratory analysis by using the sample bottle and freeze it in the icebox. The method of sample analytical 
procedure and sample preservation were followed the Standard Methods (APHA, 2005). Water sampling has been done in two different months which were in June and July 2015. Statically analysis for all parameters was conducted using Statistical Analysis System (SAS) version 9.2 (SAS, 2008). The analysis of variance (ANOVA) followed by Tukeys's studentized range test (HSD) at $\mathrm{P} \leq 0.05$ was used to evaluated significant differences in mean comparison between station and mean comparison between tides.

\section{RESULT AND DISCUSSION}

The mean of electrical conductivity was highest in the downstream (station 5) which was near to the sea. The major positively charged ions are sodium, $\left(\mathrm{Na}^{+}\right)$calcium $\left(\mathrm{Ca}^{+2}\right)$, potassium $\left(\mathrm{K}^{+}\right)$and magnesium $\left(\mathrm{Mg}^{+2}\right)$. The major negatively charged ions are chloride $\left(\mathrm{Cl}^{-}\right)$, sulfate $\left(\mathrm{SO}_{4}{ }^{-2}\right)$, carbonate $\left(\mathrm{CO}_{3}^{-2}\right)$, and bicarbonate $\left(\mathrm{HCO}_{3}{ }^{-}\right)$. The sea water is primarily consisting of sodium chloride (NaCl) (CWT, 2004).

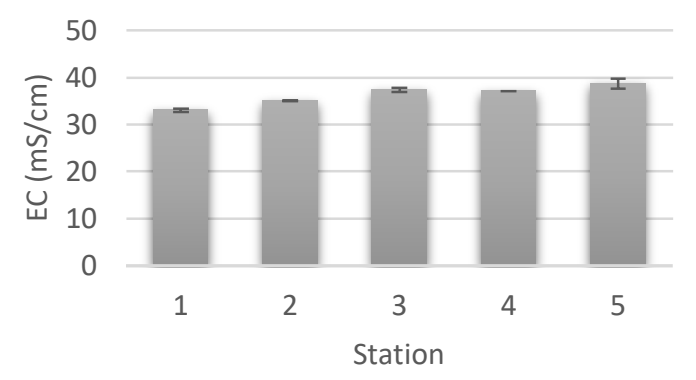

Figure 1. Mean Comparison of EC between Stations

The turbidity mean for the highest concentration was 26 NTU for station 4 while the lowest was $19.38 \mathrm{mg} / \mathrm{L}$ for station 5. The turbidity level of station 4 was the highest because of the water flowed from the other stream that connected to Jarum Mas river. The sediment or soluble solids that flown from the stream gave more turbidity level to the station 4 .

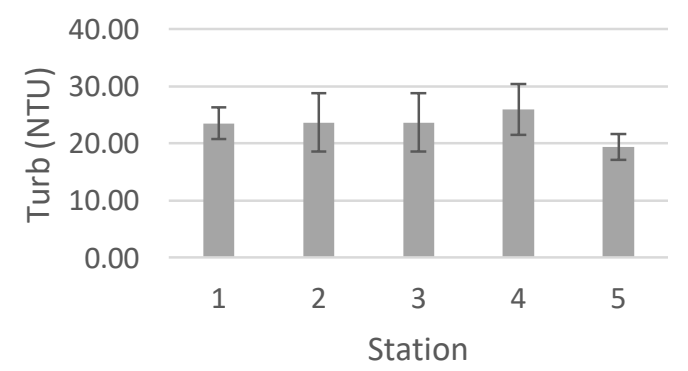

Figure 2. Mean Comparison of Turb between Stations

Figure 3 showed that the downstream was higher than the upstream with the highest mean reading was 22.69 $\mathrm{mg} / \mathrm{L}$ for station 5 while the lowest was station 1 with a mean of $20.07 \mathrm{mg} / \mathrm{L}$. Total dissolved solids (TDS) are the mineral and salt impurities dissolved in water. TDS sources can also from agricultural runoff, residential runoff, and industrial point-source pollution (Farley, 2004).

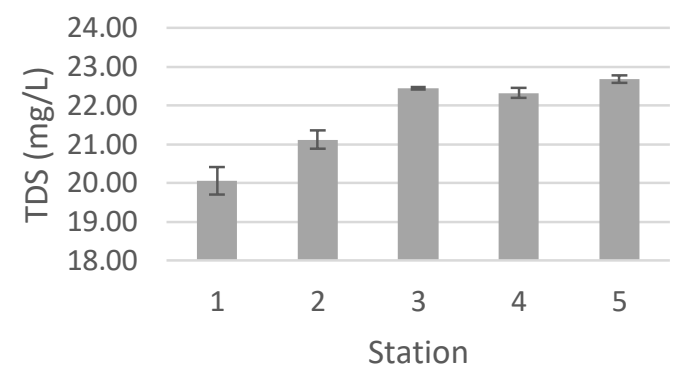

Figure 3. Mean Comparison of TDS between Stations

In Jarum Mas river situation, the sources of mineral and salt were coming from the sea that was flown into the river during high tide. Station 1 and station 2 shown a significant difference if compared to the downstream because the concentration of the mineral and salt was lower. Besides, both stations was far from the sea. The mean for the downstream was higher than the upstream. The highest was station 5 with a mean of 22.03 PSU while the lowest was station 1 with a mean of 19.50 PSU. Salinity and electrical conductivity were related because dissolved ions increase salinity as well as conductivity (CWT, 2004). Farley (2004) was said that, like conductivity, salinity was determined by the concentration of ions in solution.

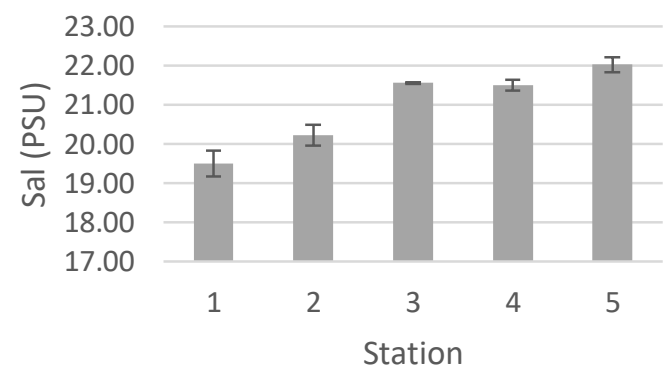

Figure 4. Mean Comparison of Sal between Stations

Station 3 had the highest temperature mean, $29.35{ }^{\circ} \mathrm{C}$ (middle stream) then followed by the downstream with a mean of $29.18^{\circ} \mathrm{C}$ while the lowest was upstream with a mean of $28.25^{\circ} \mathrm{C}$. The change of water temperature can affect the conductivity and the measurement of total dissolved solids. Farley (2004) was also said that the increased temperature can cause the ions to move more quickly. For comparison, both station 1 and station 2 of electrical conductivity and TDS showed significant concentration difference. This proved that temperature and conductivity showed a positive correlation. 


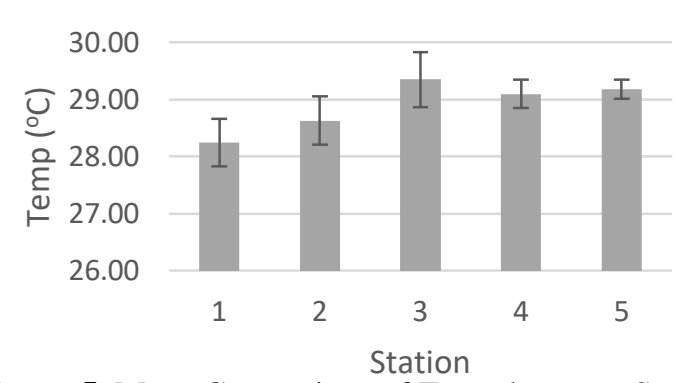

Figure 5. Mean Comparison of Temp between Stations

Figure 6 showed that station 5 had the highest mean which was $4.91 \mathrm{mg} / \mathrm{L}$ if compare to the station 1 with a mean of $2.27 \mathrm{mg} / \mathrm{L}$. The mean concentration of DO was increasing steadily from Station 1 to Station 5. This may be the influence on the dissolved oxygen concentration of the photosynthetic rate, which increases the oxygen concentration (Wheeler et al., 2003). According to Wheeler (2003), photosynthesis mainly occurred in the euphotic zone (the depth of the water that was exposed to the sunlight), where primary producers need much light.

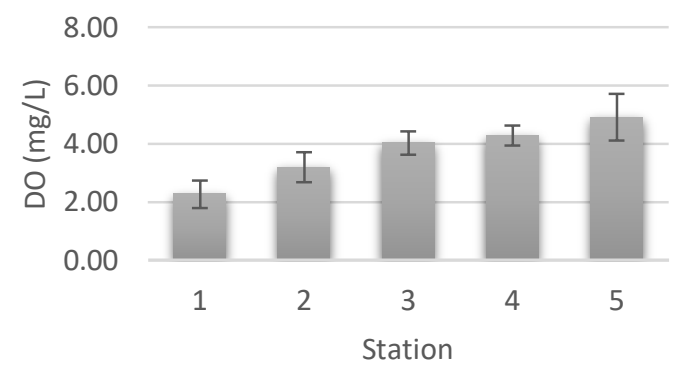

Figure 6. Mean Comparison of DO between Stations

The $\mathrm{pH}$ range for Jarum Mas river was between $6.85-$ $7.00 \mathrm{pH}$ value. The highest mean was $6.98 \mathrm{pH}$ value for station 5 while the lowest was $6.86 \mathrm{pH}$ value for station 1. It was slightly acidic. Low and high $\mathrm{pH}$ value is very harmful to the ecosystems of the river, and the recommended $\mathrm{pH}$ level of river water is around $7.4 \mathrm{pH}$ value (Rahman, 2013).

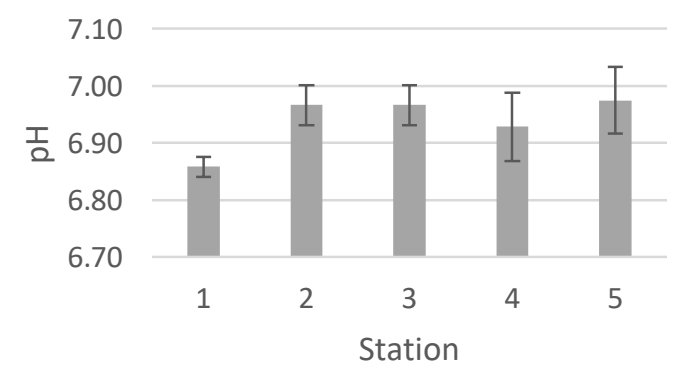

Figure 7. Mean Comparison of $\mathrm{pH}$ between Stations

The highest mean of Total Suspended Solids was 70.50 $\mathrm{mg} / \mathrm{L}$ for station 4 while the lowest was $48.33 \mathrm{mg} / \mathrm{L}$ for station 1. Like turbidity, TSS did not show a significant difference in concentration. TSS will increase if the turbidity was increasing. Past studies had been conducted and consistently showing a strong correlation between TSS and turbidity (Gippel, 1995).

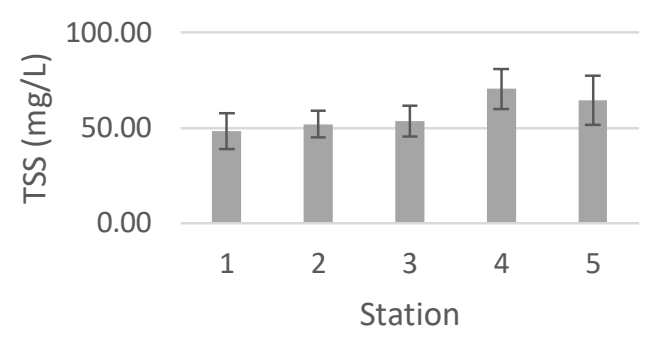

Figure 8. Mean Comparison of TSS between Stations

Statistical analysis showed that biochemical oxygen demand (BOD) in Jarum Mas river was in Class II (Good) in Water Quality Index (WQI) except for station 5 , class III (Moderate). A high BOD, greater than 6 $\mathrm{mg} / \mathrm{L}$ (class IV) often indicates polluted or eutrophic waters (USEPA, 2011). The greater the BOD, the oxygen is rapidly depleted. The consequences of high BOD were caused the aquatic organisms become stressed, suffocate, and die.

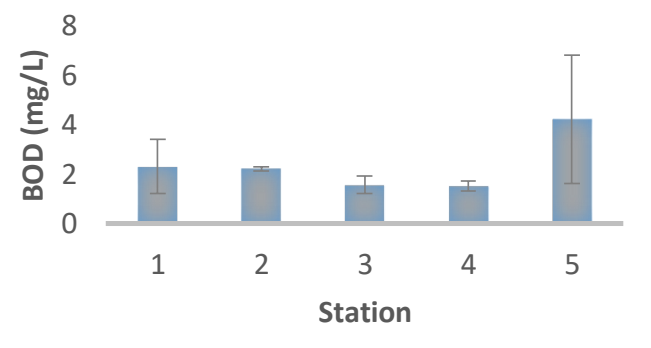

Figure 9. Mean Comparison of BOD between Stations

Besides, there was a lot of sediment accumulated at the station 5 that drifting from the other river. Based on the trends of chemical oxygen demand (COD), the highest concentration was at the upstream where it was near to the open area for agriculture. The results showed that there was a high concentration of organic or chemical. COD is preferred for estimating organic pollution (Liu et al. 2005).

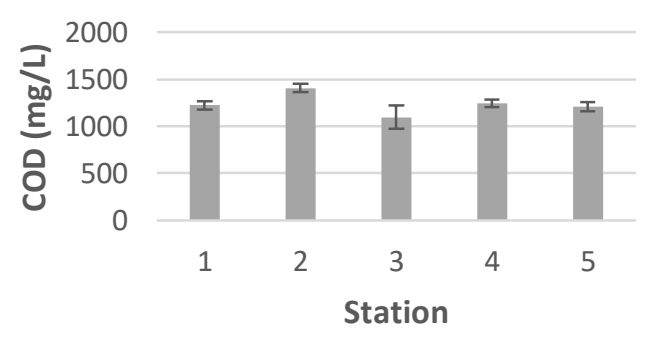

Figure 10. Mean Comparison of COD betweenStations 
The mean range of all stations was $4 \mathrm{mg} / \mathrm{L}-5 \mathrm{mg} / \mathrm{L}$. There was a relationship between COD and ammoniacal nitrogen (AN) where the natural sources of ammonia were including the decomposition or breakdown of organic waste matter, gas exchange with the atmosphere, forest fires, animal and human waste (EPA, 2013). Ammonium concentration is an indicator of new biological pollution and the use of fertilizers (Manssour \& Al-Mufti, 2010). Based on Figure 11, ammoniacal nitrogen was high because of the fertilizer used in agriculture activities at the upstream that flowed.

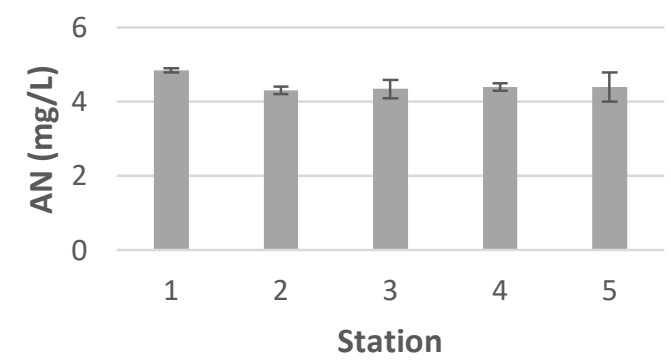

Figure 11. Mean Comparison of AN between Stations

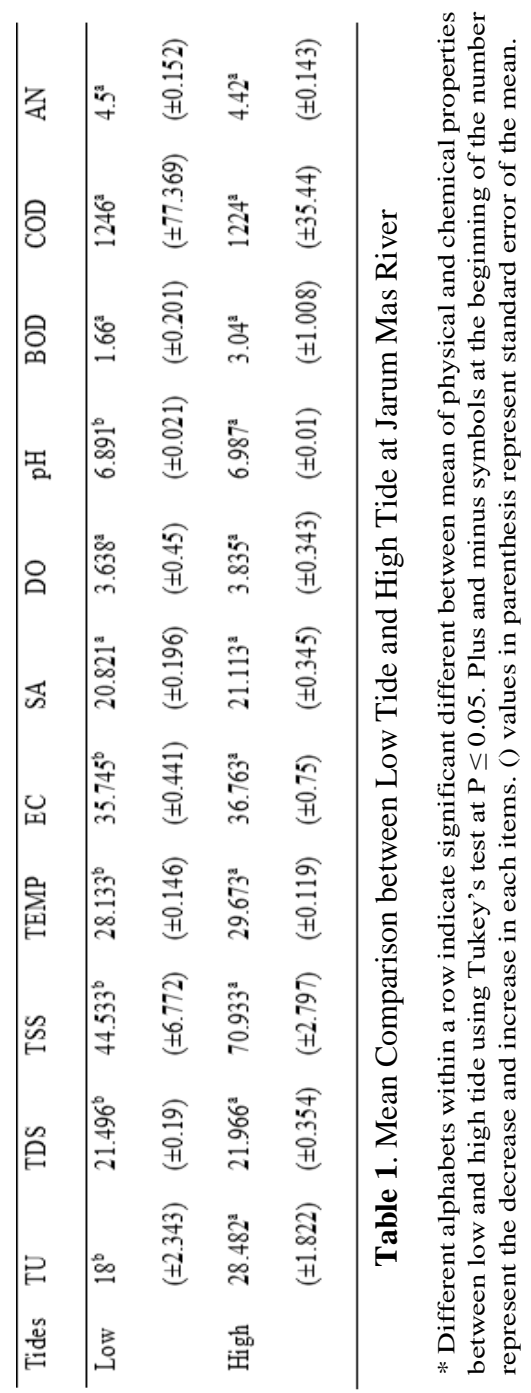

Gippel (1995) was said that past studies had proved the consistency of strong correlation between TSS and turbidity. Based on the trend of turbidity and TSS in Jarum Mas river, both of them high in concentration when high tide. During low tide, total dissolved solids (TDS), electrical conductivity (EC) and salinity were high during high tide. Like turbidity and TSS, these three parameters were also had correlation where sea water $(\mathrm{NaCl})$ was the main effect of the change of mean concentration. Temperature level was also high during high tide. Jarum Mas river was a good conductivity during high tide. So, it also good as heat conductivity as heat during the afternoon was absorbed by the salinity in water. For DO, both tides showed moderate (Class III) concentration in water quality index (WQI). As noted before, DO is important for aquatic life like algae to do photosynthesis. For pH, Jarum Mas river both showed an acidic level even though there was significant concentration difference where high tide was higher than the low tide.

Apart from that, statistical analysis showed that mean concentration of BOD was higher during high tide compared to the low tide. However, the BOD class of WQI was in Class II for low tide and class III for high tide which was good for aquatic life because USEPA (2011) had said that a high BOD which is greater than 6 $\mathrm{mg} / \mathrm{L}$ (class IV) often indicates polluted or eutrophic waters. Lastly, COD and AN were the two parameters that had the same sources of organic and chemical including the decomposition or breakdown of organic waste matter, gas exchange with the atmosphere, forest fires, animal and human waste (EPA, 2013). Both concentrations was higher during low tide which it assumed that it came from the agriculture site at the upstream that produce organic waste.

Based on Figure 12, water quality index of Jarum Mas river was in Class III for all stations except for station 4 and station 5 during High Tide which was Class IV. It was moderate water quality which needed extensive treatment if the water source was used for water supply. For fishery, it was only suitable for common economic value and tolerant species livestock drinking (DOE, 2009). 


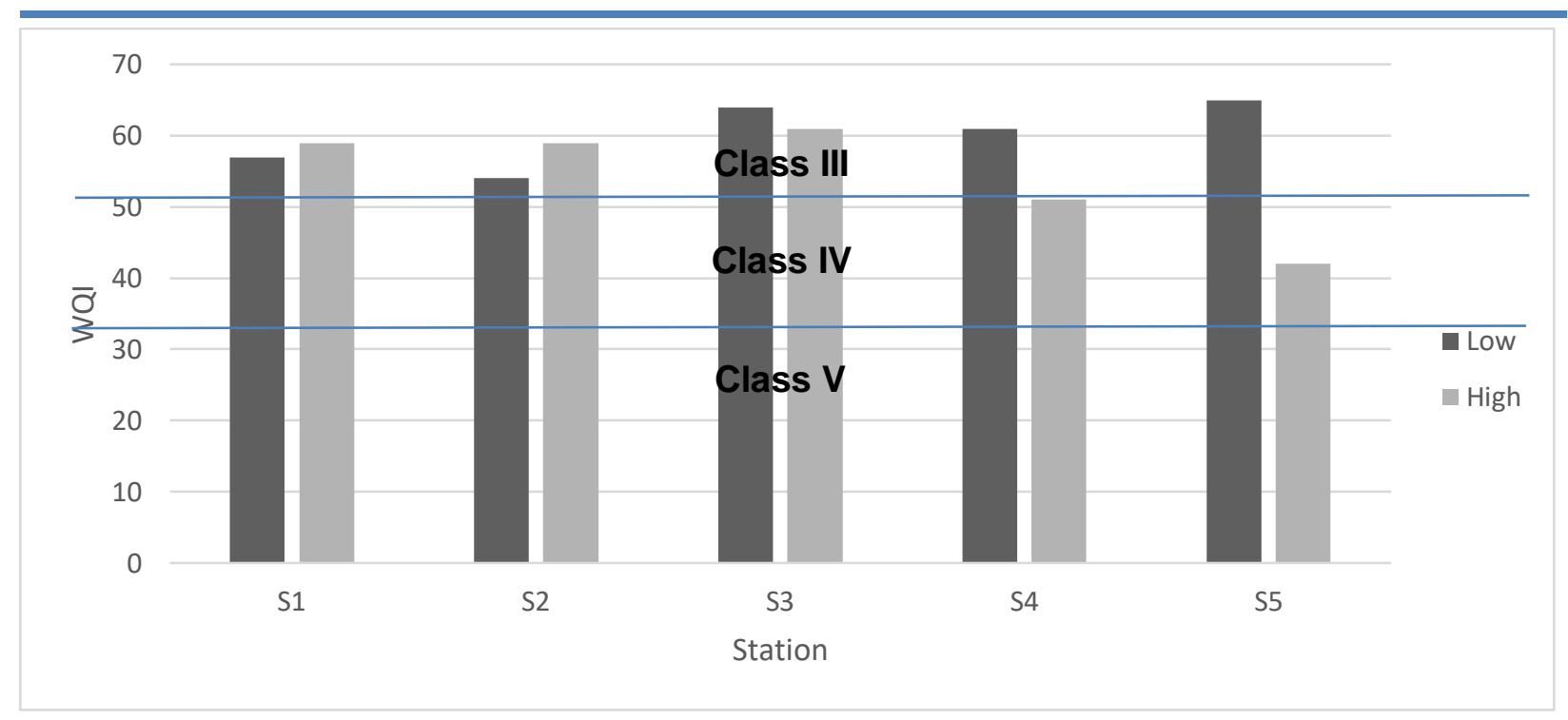

Figure 12. Water Quality Index of Jarum Mas River

\section{CONCLUSION}

Water Quality Index of Jarum Mas river was in Class III which is moderate based on Water Quality Index Scale by Department of Environmental. Chemical Oxygen Demand (COD) and Ammoniacal Nitrogen (AN) concentration were in Class $\mathrm{V}$ which was poor water quality even though overall it was in Class III. Furthermore, COD is preferred for estimating organic pollution while Ammonium concentration is an indicator of new biological pollution and the use of fertilizers. So, Ammoniacal Nitrogen was high because of the fertilizer used in agriculture activities at the upstream that flowed and contributed organic matter, a chemical from pesticide and other waste from agriculture activities. For water quality comparison between tides, there were two stations were in Class IV which were Station 4 and Station 5. It was influenced by the water that flows into the Jarum Mas river that brought along the pollution from the sea and another river.

Acknowledgements. We wish to thank Universiti Putra Malaysia for funding this research funding project. We also have greatly appreciated to Forestry Department of Matang Mangrove Forest for their cooperation during the sampling and giving permission for us to explore along the Jarum Mas river. Lastly, thanks to Faculty of Forestry Universiti Putra Malaysia for preparing us transportation along the sampling period.

\section{References}

1. Alongi, D. M. (2008). Mangrove forests: resilience, protection from tsunamis, and responses to global climate change. Estuarine, Coastal and Shelf Science, 76(1), 1-13.

2. APHA (American Public Health Association).2005. Standard methods for the Examination of water and wastewater. $21^{\text {st }}$ Edn Washington, DC: American Public Health Association.
3. Clean Water Team (CWT) 2004. Electrical conductivity/salinity Fact Sheet, FS-3.1.3.0(EC). in: The Clean Water Team Guidance Compendium for Watershed Monitoring and Assessment, Version 2.0. Division of Water Quality, California State Water Resources Control Board (SWRCB), Sacramento, CA

4. DOE (Department of Environment). 2009. Water Quality (River) monitoring system/programme and pollution control. Hashim Daud (Director, Water and Marine Division). Ministry of Natural Resources and Environment.

5. EPA (Environmental Protection Agency), Aquatic Life Ambient Water Quality Criteria for Ammonia - Freshwater (2013). Available

http://water.epa.gov/scitech/swguidance/standards/criteria/aqlife/ ammonia/index.cfm. Accessed on August 17, 2015.

6. Gippel, C. J. (1995). Potential of turbidity monitoring for measuring the transport of suspended solids in streams. Hydrological processes, 9(1), 83-97.

7. Holmes-Farley, R. What is TDS? Reefkeeping. 2004, 4. Available at www.reefkeeping.com/issues/2004-04/rhf/feature/. Accessed on Oct 15, 2015

8. Latiff, A. (2012). Conservation strategies for endangered mangrove swamp forests in Malaysia. Pakistan J Bot, 44, 27-36.

9. Liu, L., Ji, H., Liu, Y., \& Xin, H. (2005). Chemical oxygen demand of seawater determined with a microwave heating method. Journal of Ocean University of China, 4(2), 152-156.

10. Manssour, K., \& Al-Mufti, B. (2010). Influence of Industrial, Agricultural and Sewage Water Discharges on Eutrophication of Quttina Lake. Jordan Journal of Civil Engineering, 4(4).

11. Rahman, M. M., Rahman, T. M., Rahaman, M. S., Rahman, F., Ahmad, J. U., Shakera, B., \& Halim, M. A. (2013). Water quality of the world's largest mangrove forest. Can Chem Trans, 1(2), 141-156.

12. USEPA (United States Environmental Protection Agency). 2011. Water $>$ Water Pollutants. Available at http://www.epa.gov/ebtpages/wastewaterpollutants.html. Accessed on September 23, 2015.

13. Wheeler, D. L., Church, D. M., Federhen, S., Lash, A. E., Madden, T. L., Pontius, J. U., \& Wagner, L. (2003). Database resources of the National Center for Biotechnology. Nucleic acids research, 31(1), 28-33.

14. WWF (World Wide Fund). 2013. Mangrove Forest. Available at http://www.wwf.org.my/. Accessed on September 8, 2015. 